\title{
Characterization of a resilient seagrass meadow during a decline period
}

\author{
Bárbara Ondiviela ${ }^{1,2}$, Lina Fernández ${ }^{2,3}$, Araceli Puente ${ }^{1}$, Gerardo García-Castrillo ${ }^{2,4}$, \\ José A. Juanes ${ }^{1}$ \\ ${ }^{1}$ Environmental Hydraulics Institute "IH Cantabria", Universidad de Cantabria, Isabel Torres, 15, \\ Parque Científico y Tecnológico de Cantabria, 39011 Santander, Spain. \\ (BO) (Corresponding author) E-mail: ondiviela@unican.es. ORCID-iD: https://orcid.org/0000-0001-6902-1166 \\ (AP) E-mail: puentea@unican.es. ORCID-iD: https://orcid.org/0000-0001-7627-4743 \\ (JAJ) E-mail: juanesj@unican.es. ORCID-iD: https://orcid.org/0000-0003-1825-2858 \\ ${ }^{2}$ Asociación Científica de Estudio Marinos (ACEM), Juan José Pérez del Molino, 16, 39006 Santander, Spain. \\ (LF) E-mail: linafvelez@yahoo.com. ORCID-iD: https://orcid.org/0000-0002-9621-3152 \\ (GG-C) E-mail: ggc@mmc.e.telefonica.net. ORCID-iD: https://orcid.org/0000-0001-6795-1212 \\ ${ }^{3}$ Consejería de Ganadería, Pesca y Desarrollo Rural, Gobierno de Cantabria, Avda. Albert Einstein, 2, \\ Parque Científico y Tecnológico de Cantabria, 39011 Santander, Spain. \\ ${ }^{4}$ Museo Marítimo del Cantábrico, Gobierno de Cantabria, Promontorio de San Martín s/n, 39004 Santander, Spain.
}

\begin{abstract}
Summary: Seagrasses are globally threatened ecosystems with essential ecological roles. An important limitation in seagrass conservation efforts is the poor understanding of resilient meadows. The present work studies a meadow, which maintained a large population of Zostera marina and Zostera noltei, during the decline of seagrasses in the Bay of Santander (from 1984 to 2000). The work examines resilience parameters related to the biological traits (biomass, density, length and width of the leaves) and to the associated benthic assemblages. The maturity of the meadow and the changing environmental conditions induced by the torrential regime of the Miera River, have likely improved the resistance to the periods of stress. The adaptation to these fluctuating conditions is reflected in a high seasonal and spatial variability in the biomass, density, morphological traits and benthic assemblages. These variations are related to the summer peaks in the PAR, the sea surface temperature and the freshwater influence along the discharge of the Miera River. This work provides the first seagrass data in Cantabria. The data are dated in the early 2000s and constitute a baseline study for the Bay of Biscay.
\end{abstract}

Keywords: Zostera marina; Zostera noltei; benthic fauna; Bay of Santander; plant traits variability.

Caracterización de una pradera resiliente de fanerógamas marinas durante períodos de regresión

Resumen: Las praderas de fanerógamas marinas son ecosistemas globalmente muy amenazados, con funciones ecológicas esenciales. Una limitación importante para su conservación es el limitado conocimiento sobre el papel de las praderas resilientes. El presente trabajo aborda la caracterización de una pradera resiliente, durante el declive de las poblaciones de Zostera marina y Zostera noltei en la bahía de Santander (período 1984-2001). El trabajo examina parámetros de resiliencia relacionados con los rasgos biológicos (biomasa, densidad, longitud y anchura de las hojas) y con las comunidades bentónicas asociadas. La madurez de la pradera y unas condiciones ambientales muy cambiantes, inducidas por el carácter torrencial del río Miera, han favorecido probablemente su resistencia frente a los períodos de estrés. La adaptación a estas condiciones se refleja en una alta variabilidad estacional y espacial en la biomasa, la densidad, los rasgos morfológicos y las asociaciones bentónicas. Estas fluctuaciones parecen responder a los picos de PAR y temperatura del agua y al gradiente a lo largo de la desembocadura del río Miera. Este trabajo proporciona los primeros datos de fanerógamas marinas en Cantabria. Los datos se recogieron a principios de la década de 2000 y constituyen un estudio de referencia para el Golfo de Vizcaya.

Palabras clave: Zostera marina; Zostera noltei; fauna bentónica; bahía de Santander; variabilidad de rasgos vegetales.

Citation/Como citar este artículo: Ondiviela B., Fernández L., Puente A., García-Castrillo G., Juanes J.A. 2018. Characterization of a resilient seagrass meadow during a decline period. Sci. Mar. 82(1): 67-75. https://doi.org/10.3989/ scimar.04616.18A

Editor: E. Cebrián.

Received: February 2, 2017. Accepted: December 18, 2017. Published: January 30, 2018.

Copyright: (C) 2018 CSIC. This is an open-access article distributed under the terms of the Creative Commons Attribution 4.0 International (CC BY 4.0) License. 


\section{INTRODUCTION}

For decades, Zostera marina (Linneo) and Zostera noltei (Hornemann) have faced a severe decline across their range (Orth et al. 2006, Waycott et al. 2009, Short et al. 2011). Although the recovery of degraded ecosystems without direct restoration intervention is rare, in recent years, certain coastal areas have displayed considerable resilience (Lotze et al. 2006, Dolch et al. 2013, Folmer et al. 2016). Unfortunately, little attention has been given in the scientific literature to resilient ecosystems, and resilience drivers remain poorly understood (Macreadie et al. 2014, Yaakub et al. 2014, Hughes et al. 2016).

To halt degradation and promote recovery, management requires a change in emphasis to enhance seagrass ecosystem resilience (Unsworth et al. 2015). In addition to the ability to recover that has been demonstrated by small fast-growing seagrass species such as Z. marina and Z. noltei (Davis et al. 2016), seagrass meadows also need to possess traits of resistance in order to remain resilient to drivers of ecosystem change (Bergmann et al. 2010).

Unsworth et al. (2015) classify seagrass resilience traits into biological features of seagrasses (e.g. leaf width and length, density and tolerance to abiotic features), biological features of supporting ecosystems (e.g. species assemblages) and biophysical environment (e.g. water quality). Thus, large, dense, non-fragmented meadows in healthy environments and with good trophic interactions might enhance the resilience of seagrasses (Ehlers et al. 2008).

The Bay of Santander is the largest estuary in northern Spain (Bay of Biscay). This tidal ecosystem shelters perennial seagrass meadows of $Z$. nolte $i$ in the intertidal and $Z$. marina in the low tidal and shallow subtidal zones. Recently, Calleja et al. (2017) reported a decline in $Z$. noltei that occurred in the Bay of Santander between 1984 and the early 2000s. During the decline they observed that one of the meadows (La Barquería) maintained large populations of seagrasses and showed uninterrupted growth. They concluded that the resistance of this meadow to the changes that had affected seagrass meadows in the Bay of Santander in past decades could be a reflection of the resilience.

Where seagrasses have traditionally existed, the combination of maturity and changing environmental conditions could be enabling a healthier and more resilient community (Calleja et al. 2017). The meadow is subjected to episodic storm events in the river basin that result in severely changing conditions arising from large amounts of suspended solids reaching the estuary from the eroded watershed. Consequently, seagrasses in this area have adapted to tolerating periodic phases of turbidity and severe changes in temperature, light, salinity and nutrient concentrations.

The objective of this work was to study the resilient meadow of La Barquería at the precise moment when the population of seagrasses was decreasing in the Bay of Santander (in the year 2000). Based on Unsworth et al. 2015 , the meadow was characterized by analysing a selection of resilience biological features, which in-

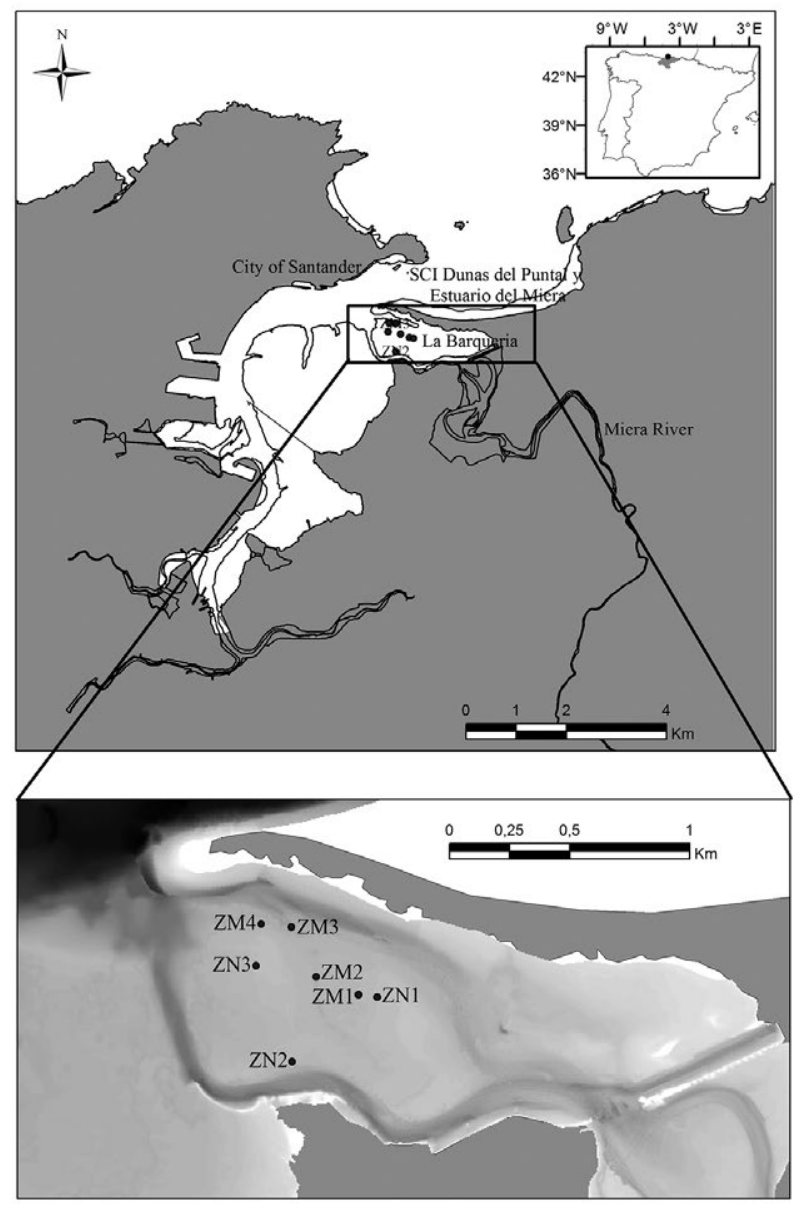

Fig. 1. - Location of the study area and sampling sites in the Bay of Santander for Zostera marina (ZM1-ZM4) and Zostera noltei (ZN1-ZN3). The study area is delimited within the box.

cluded habitat characteristics, trait variability in shoot density, aboveground biomass, leaf length and width, and benthic assemblages for Zostera marina and Zostera noltei beds along seasonal and spatial gradients.

\section{MATERIALS AND METHODS}

\section{Study site}

The study was conducted on intertidal beds of Zostera marina and Zostera noltei in the estuary of the Bay of Santander (Bay of Biscay, northern Spain). The study area of La Barquería (Fig. 1) is a tidal flat (73.5 ha) included in the Site of Community Importance (SCI) under the European Habitats Directive (92/43/EEC) "Dunas del Puntal y Estuario del Miera" (ES1300005). It is located at the confluence between the Miera River, the main freshwater source in the estuary $\left(8.2 \mathrm{~m}^{3} \mathrm{~s}^{-1}\right.$ multi-year average) and the marine estuarine waters. Mean tidal range in the estuary is $2.8 \mathrm{~m}$ (Galván et al. 2010). The estuary is completely renovated twice a day and the main disturbances are shellfish extraction, port activities, dredging of the navigation channels and anchoring (Ondiviela et al. 2013). An important physical disturbance is the input of sediments from the Miera River. The basin of the river is short, steep and highly 
Table 1. - Mean annual \pm standard deviation (2000-2001) for grain size fractions (\%), organic matter $(\%)$, water and sediment temperature $\left({ }^{\circ} \mathrm{C}\right)$, and salinity (psu) in the Zostera marina (ZM1-ZM4) and Zostera noltei (ZN1-ZN3) beds.

\begin{tabular}{|c|c|c|c|c|c|c|c|c|}
\hline & Depth (m) & Gravel (\%) & Sand $(\%)$ & Mud (\%) & $\begin{array}{l}\text { Organic } \\
\text { matter }(\%)\end{array}$ & $\begin{array}{c}\text { Seawater } \\
\text { temperature } \\
\left({ }^{\circ} \mathrm{C}\right)\end{array}$ & $\begin{array}{c}\text { Sediment } \\
\text { temperature } \\
\left({ }^{\circ} \mathrm{C}\right)\end{array}$ & Salinity \\
\hline \multicolumn{9}{|l|}{ Zostera marina } \\
\hline ZM1 & -0.82 & $1.0 \pm 0.6$ & $82.2 \pm 10.1$ & $15.7 \pm 10.3$ & $6.0 \pm 1.5$ & $19.5 \pm 4.0$ & $19.0 \pm 3.6$ & $30.63 \pm 7.8$ \\
\hline ZM2 & -1.66 & $1.1 \pm 0.8$ & $74.4 \pm 7.0$ & $23.7 \pm 6.2$ & $8.6 \pm 3.2$ & $19.0 \pm 3.6$ & $19.4 \pm 4.1$ & $30.63 \pm 7.8$ \\
\hline ZM3 & -1.55 & $1.0 \pm 1.1$ & $91.6 \pm 2.5$ & $7.1 \pm 1.6$ & $5.1 \pm 1.9$ & $19.7 \pm 3.6$ & $18.8 \pm 3.5$ & $34.3 \pm 1.63$ \\
\hline ZM4 & -1.41 & $1.3 \pm 0.8$ & $88.6 \pm 3.4$ & $9.1 \pm 2.4$ & $7.0 \pm 0.8$ & $18.5 \pm 3.5$ & $20.0 \pm 4.6$ & $34.3 \pm 1.63$ \\
\hline \multicolumn{9}{|l|}{ Zostera noltei } \\
\hline ZN1 & -0.58 & $0.8 \pm 0.6$ & $92.2 \pm 2.1$ & $6.2 \pm 2.5$ & $3.8 \pm 1.5$ & $19.5 \pm 4.0$ & $19.3 \pm 3.8$ & $30.63 \pm 7.8$ \\
\hline $\mathrm{ZN} 2$ & -0.55 & $0.4 \pm 0.4$ & $92.8 \pm 2.9$ & $6.3 \pm 3.4$ & $4.1 \pm 0.6$ & $18.1 \pm 3.2$ & $18.8 \pm 3.8$ & $30.63 \pm 7.8$ \\
\hline $\mathrm{ZN} 3$ & -0.52 & $0.4 \pm 0.2$ & $95.7 \pm 1.4$ & $3.1 \pm 1.2$ & $3.9 \pm 1.0$ & $18.7 \pm 3.5$ & $20.3 \pm 3.8$ & $34.3 \pm 1.63$ \\
\hline
\end{tabular}

deforested. These characteristics cause erosion during and after heavy rains, which results in large amounts of suspended solids in the estuary that influence its physical and chemical characteristics (e.g. light attenuation).

\section{Data collection}

Data were collected from April 2000 to March 2001. Two environmental factors were considered to characterize the meadow: the spatial factor (along the discharge channel of the Miera River) and the seasonal factor (throughout a year cycle). Sampling sites were located following the discharge channel of the river (Fig. 1). Four sites were selected on the Z. marina bed (ZM1, ZM2, ZM3, ZM4) and three sites on the Z. noltei bed (ZN1, ZN2, ZN3).

To study the effect of seasonality and the spatial factor on the aboveground biomass $\left(\mathrm{g} \mathrm{DW} \mathrm{m}^{-2} ; 70^{\circ} \mathrm{C} ; 48\right.$ h), density (no. shoots $\mathrm{m}^{-2}$ ) and morphological leaf traits (length and width; $\mathrm{cm}$ ), four replicate samples $\left(100 \mathrm{~cm}^{2}\right.$ and $15 \mathrm{~cm}$ deep, extracted with quadrant) were collected monthly from April to September and bimonthly from October to March at each sampling site. Moreover, one sample $\left(2500 \mathrm{~cm}^{2}\right.$ and $15 \mathrm{~cm}$ depth, extracted with quadrant) was collected quarterly (January, April, July, October) to study the benthic infauna (no. individuals $\mathrm{m}^{-2}$ ) and to characterize the sediment. All of the leave shoots were evaluated for trait statistics (mean \pm standard error). Benthic invertebrate samples were fixed and preserved with $4 \%$ buffered formalin and sieved through a 1-mm mesh. Samples were sorted and identified to their lowest possible taxonomic level. Grain size was determined from $100-\mathrm{g}$ dry weight samples $\left(105^{\circ} \mathrm{C} ; 24 \mathrm{~h}\right)$ following Folk (1954) and using the Wentworth scale (Wentworth 1922). Organic matter was estimated using the method of calcination $\left(550^{\circ} \mathrm{C} ; 6 \mathrm{~h}\right)$ for 50 -g dry weight subsamples $\left(105^{\circ} \mathrm{C} ; 24 \mathrm{~h}\right)$. Salinity was measured with CTD (Sea-Bird SBE 19 plus V2) and sediment and water temperature were measured with a portable HANNA HI 9023 thermometer. Photosynthetically active radiation (PAR, einstein $\mathrm{m}^{-2}$ day $^{-1}$ ) was obtained from the GlobColour satellite imagery dataset.

\section{Statistical analysis}

Data were examined for equal variance (Bartlett test) and normal distribution (Kolmogorov-Smirnov test). Seasonal variations (independent variable) in the density, biomass and plant traits (dependent variables) were analysed with a one-way ANOVA test $(n=9 /$ months; April, May, June, July, August, September, November, January and March). Data with a non-normal distribution were transformed $(\log (\mathrm{Y}+1)$. Invertebrate abundance (ind. $\mathrm{m}^{-2}$ ), species richness (number of species) and diversity (Shannon-Wiener index) were calculated using PRIMER 6. A non-metric multidimensional scaling analysis (Kruskal and Wish 1978) was used to represent the reliability of the assignment performed and the similarity gradient among the sample sites. The analysis was performed on square-root transformed abundance data using the Bray-Curtis similarity index.

\section{RESULTS}

\section{Habitat characteristics}

There were no differences in temperature along the discharge channel of the Miera River. Salinity values ranged from $30.63 \pm 7.8$ (ZM1) to $34.3 \pm 1.63$ (ZM4), between the sites with the lowest and the highest marine influence, respectively (Table 1). The meadow was characterized by grain size gradient, increasing from riverine and deepest sites (ZM1, ZM2, ZN1, ZN2) to the marine and shallowest areas (ZM3, ZM4, ZN3). $Z$. marina occurred at the muddiest $(23.7 \pm 6.2 \%$; ZM2) and deepest meadow ( $-1.66 \mathrm{~m}$; ZM2) over sediments with the maximum organic matter content $(8.6 \pm 3.2 \%$; ZM2), while Z. noltei was found in shallow $(0.58 \mathrm{~m}$; ZN1) and sandy intertidal zones $(95.7 \pm 1.4 \%)$.

\section{Seasonal and spatial variations of biomass, shoot density and plant traits}

The bed of $Z$. marina showed significant seasonal differences $(<0.01)$ in aboveground biomass, density, leaf length and leaf width. Aboveground biomass and density showed differences between July-September and November-January (Table 2), while significant differences in leaf length and width were found between July-September and January-April $(<0.01)$. Mean annual maximum $\left(113 \pm 120.96 \mathrm{~g} \mathrm{DW} \mathrm{m}^{-2} ; 1107 \pm 1084\right.$ shoots $\mathrm{m}^{-2}$ ) and minimum (13 g DW $\pm 15.77 \mathrm{~m}^{-2}$; $328 \pm 346.5$ shoots $\mathrm{m}^{-2}$ ) biomass and density values occurred in August and June, respectively (Fig. 2). Maximum leaf length and width occurred in September and July, respectively $(29.9 \mathrm{~cm} ; 0.45 \mathrm{~cm})$ and minimum values in March $(10.5 \mathrm{~cm} ; 0.31 \mathrm{~cm})$. 
70 B. Ondiviela et al.

Table 2. - The effects of months on shoot density (no. shoots $\mathrm{m}^{-2}$ ), aboveground biomass $\left(\mathrm{g} \mathrm{DW} \mathrm{\textrm {m } ^ { - 2 }}\right.$ ), leaf length $(\mathrm{cm})$ and leaf width $(\mathrm{cm})$ in the Zostera marina and Zostera noltei beds. Effects are analysed using one-way ANOVA ( $\mathrm{n}=9 /$ months; <0.0001).

\begin{tabular}{lcccc}
\hline & SS & df & F-ratio & P-value \\
\hline Zostera marina & & & & \\
$\quad$ Shoot density & $3.95 \mathrm{E}+06$ & 8 & 3.17 & 0.0058 \\
Aboveground biomass & $7.05 \mathrm{E}+04$ & 8 & 4.2 & 0.0007 \\
Leaf length & $6.43 \mathrm{E}+05$ & 8 & 46.14 & 0.0000 \\
$\quad$ Leaf width & 46141 & 8 & 46.14 & 0.0000 \\
Zostera noltei & & & & \\
$\quad$ Shoot density & $2.25 \mathrm{E}+07$ & 8 & 2.4 & 0.0287 \\
Aboveground biomass & 1.75 & 8 & 1.31 & 0.2591 \\
Leaf length & 131000 & 8 & 23.29 & 0.0000 \\
Leaf width & 1170 & 8 & 95.58 & 0.0000 \\
\hline
\end{tabular}
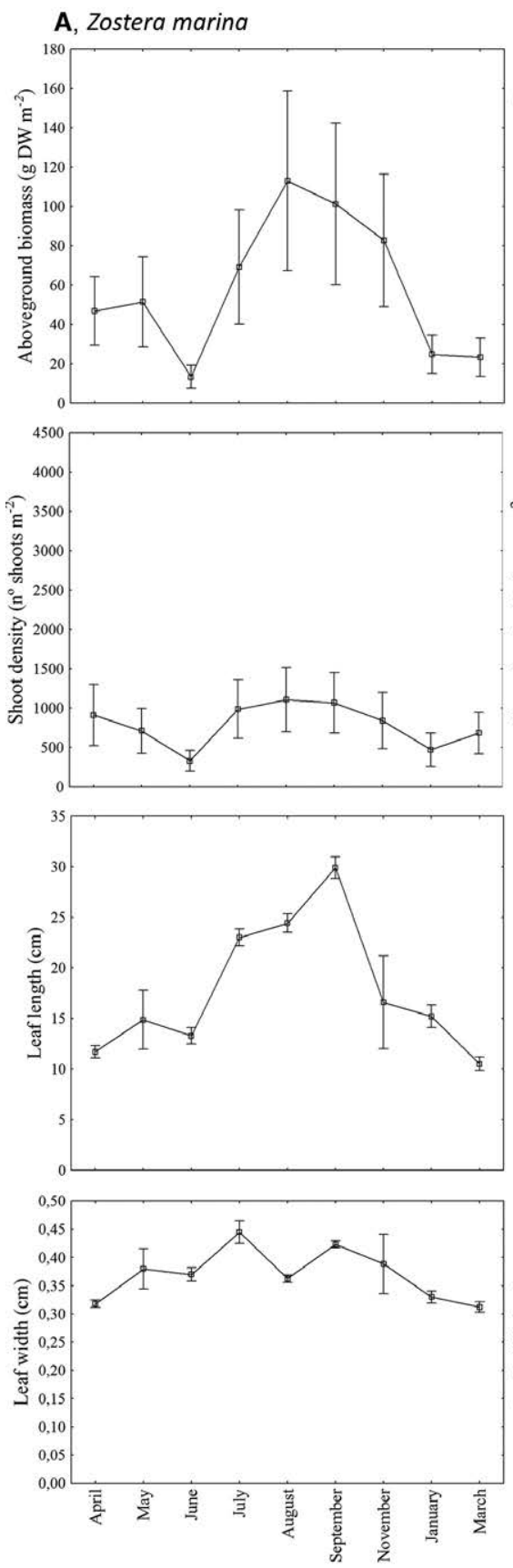

In the $Z$. noltei bed, seasonal variations in biomass were not significant (Table 2; Fig. 2). The maximum value was recorded in July $\left(50.72 \pm 50.98 \mathrm{~g} \mathrm{DW} \mathrm{m}^{-2}\right)$ and the minimum value in April $(14.02 \pm 16.68 \mathrm{~g} \mathrm{DW}$ $\left.\mathrm{m}^{-2}\right)$. Density showed significant differences $(<0.05)$ between July $\left(3357.14 \pm 1937.93\right.$ shoots $\mathrm{m}^{-2}$ ) and January $\left(1196.43 \pm 777.87\right.$ shoots $\left.\mathrm{m}^{-2}\right)$. The average shoot density was $2258 \pm 1805$ shoots $\mathrm{m}^{-2}$. The maximum length and width for leaf traits were found in September and June $(16.4 \mathrm{~cm} ; 0.173 \mathrm{~cm})$, and the minimum ones in November and January $(7.1 \mathrm{~cm} ; 0.107 \mathrm{~cm})$. Differences between July-September and January-April were significant for both parameters $(<0.01)$.

\section{B, Zostera noltei}
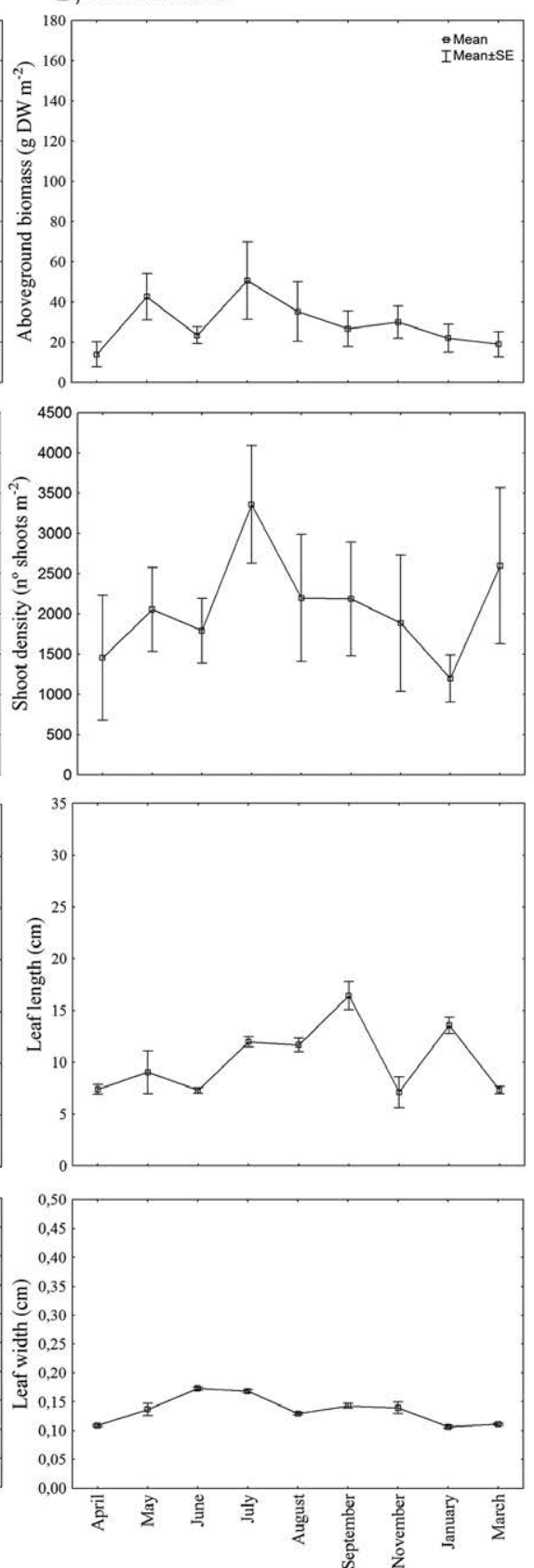

Fig. 2. - Seasonal mean \pm standard error (2000-2001) for aboveground biomass ( $\mathrm{g} \mathrm{DW} \mathrm{m}^{-2}$ ), shoot density (no. shoots $\left.\mathrm{m}^{-2}\right)$, leaf length $\left(\mathrm{cm}^{2}\right)$ and leaf width $(\mathrm{cm})$ in Zostera marina $(\mathrm{A})$ and Zostera noltei beds $(\mathrm{B})$. 

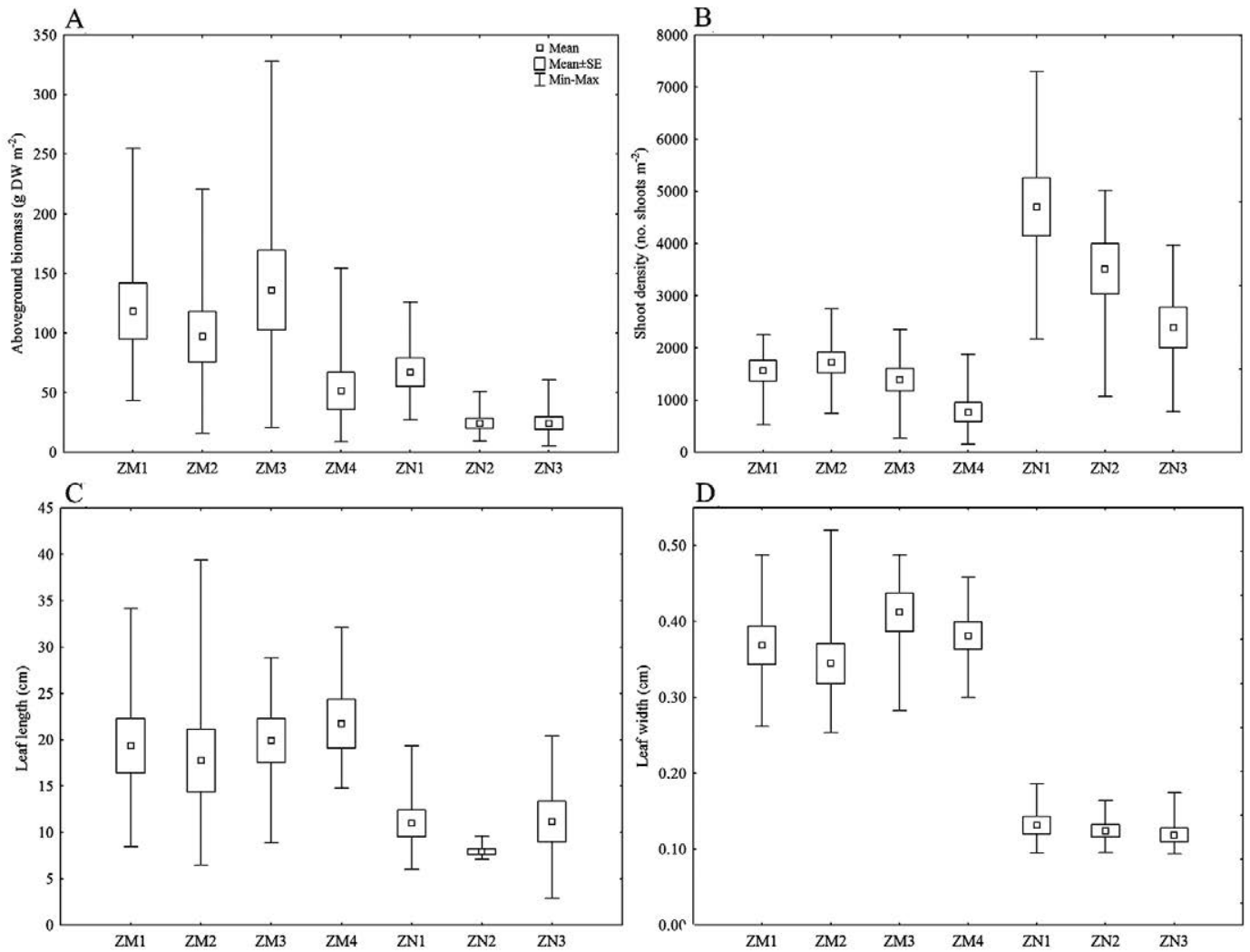

Fig. 3. - Seasonal mean \pm standard error (2000-2001) for aboveground biomass ( $\mathrm{g} \mathrm{DW} \mathrm{m}^{-2}$ ) (A), shoot density (no. shoots $\left.\mathrm{m}^{-2}\right)(\mathrm{B})$, leaf length $(\mathrm{cm})(\mathrm{C})$ and lead width $(\mathrm{cm})(\mathrm{D})$ at the sampling sites of Zostera marina (ZM1-ZM4) and Zostera noltei (ZN1-ZN3) beds.

The meadow showed a spatial gradient in shoot density and aboveground biomass, which increased with the riverine influence (Fig. 3). No spatial gradients were detected for leaf length or width. The minimum mean biomass $\left(51.44 \pm 47.06 \mathrm{~g} \mathrm{DW} \mathrm{m}^{-2}\right)$ and shoot densities $\left(769 \pm 543.8\right.$ shoots $\left.\mathrm{m}^{-2}\right)$ of the $Z$. marina bed were observed at the estuarine sites (ZM4), whereas the maximum biomass $(135.89 \pm 100.41 \mathrm{~g}$ DW $\mathrm{m}^{-2}$ ) and densities $\left(1722 \pm 591.4\right.$ shoots $\left.\mathrm{m}^{-2}\right)$ were registered at the central sites (ZM2). The spatial gradient was especially noteworthy for the $Z$. noltei bed. The minimum biomass $\left(24.17 \pm 12.32 \mathrm{~g} \mathrm{DW} \mathrm{m}^{-2}\right)$ and density $\left(2593 \pm 1068\right.$ shoots $\left.\mathrm{m}^{-2}\right)$ occurred at the central and estuarine sites (ZN3), whereas the maximum shoot density $\left(4384 \pm 1,461\right.$ shoots $\left.\mathrm{m}^{-2}\right)$ and biomass $\left(67.19 \pm 35.94 \mathrm{~g} \mathrm{DW} \mathrm{m}^{-2}\right)$ occurred at the sites with high freshwater influence (ZN1).

\section{Benthic assemblages}

The total species richness of benthic macrofauna was 101 species, which included 16 Gastropoda, 25 Bivalvia, 13 Decapoda, 33 Polychaeta and 14 species representing other faunal groups. The species richness

Table 3. - Frequency of occurrence (\%) and mean annual abundance (ind. $\mathrm{m}^{-2} \pm$ standard deviation and percentage) of the most abundant taxa ( $>60 \%$ of frequency) found at sampling sites in Zostera marina and Zostera noltei beds.

\begin{tabular}{|c|c|c|c|}
\hline & Frequency $(\%)$ & Mean annual abundance & Mean annual abundance $(\%)$ \\
\hline \multicolumn{4}{|l|}{ Zostera marina } \\
\hline Rissoa parva & 100 & $1360 \pm 341.8$ & 26.5 \\
\hline Bittium reticulatum & 100 & $728 \pm 179.4$ & 14.2 \\
\hline Abra alba & 100 & $304 \pm 56.6$ & 5.9 \\
\hline Notomastus latericius & 100 & $179 \pm 49.4$ & 3.5 \\
\hline Hinia reticulata & 100 & $173 \pm 22.0$ & 3.4 \\
\hline Loripes lacteus & 94 & $336 \pm 56.7$ & 6.5 \\
\hline Euclymene oerstedii & 94 & $313 \pm 63.6$ & 6.1 \\
\hline Marphysa belli & 94 & $79 \pm 21.0$ & 1.5 \\
\hline Hydrobia ulvae & 69 & $1070 \pm 717.4$ & 20.8 \\
\hline Total $(\mathrm{n}=16)$ & & $5134 \pm 3171.7$ & 100 \\
\hline \multicolumn{4}{|l|}{ Zostera noltei } \\
\hline Hinia reticulata & 100 & $131 \pm 23.8$ & 2.5 \\
\hline Hydrobia ulvae & 92 & $3250 \pm 1327$ & 62.5 \\
\hline Abra alba & 92 & $86 \pm 23.4$ & 1.7 \\
\hline Venerupis sp. & 92 & $46 \pm 7.9$ & 0.9 \\
\hline Bittium reticulatum & 83 & $876 \pm 292.3$ & 16.8 \\
\hline Total $(\mathrm{n}=12)$ & & $5201 \pm 6047.0$ & 100 \\
\hline
\end{tabular}




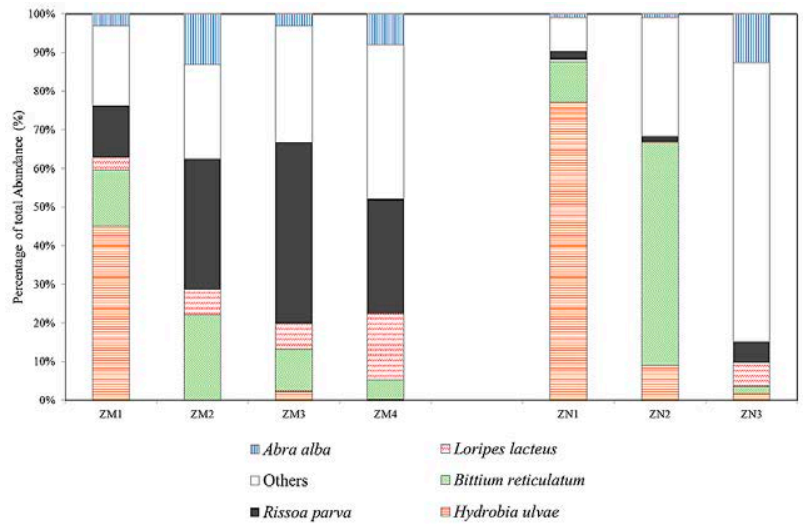

Fig. 4. - Total abundance (\%) of the main benthic macrofauna species observed at the sampling sites of Zostera marina (ZM1-ZM4) and Zostera noltei (ZN1-ZN3) beds.

of the Z. marina bed was 88 species, and 26 of these species were only present in this bed. The mean annual abundance was 5134 ind. $\mathrm{m}^{-2}$ and the highest mean annual abundance was shown by the Gastropods Rissoa parva (1360 ind. $\mathrm{m}^{-2}$ ) and Hydrobia ulvae (1070 ind. $\mathrm{m}^{-2}$ ). The most frequently occurring species (100\%) were Rissoa parva, Bittium reticulatum, Abra alba, Notomastus latericius and Hinia reticulate (Table 3 ).

Seventy-eight taxa were identified in the Z. noltei bed, 13 of which were exclusively associated with this

\section{A, Zostera marina}
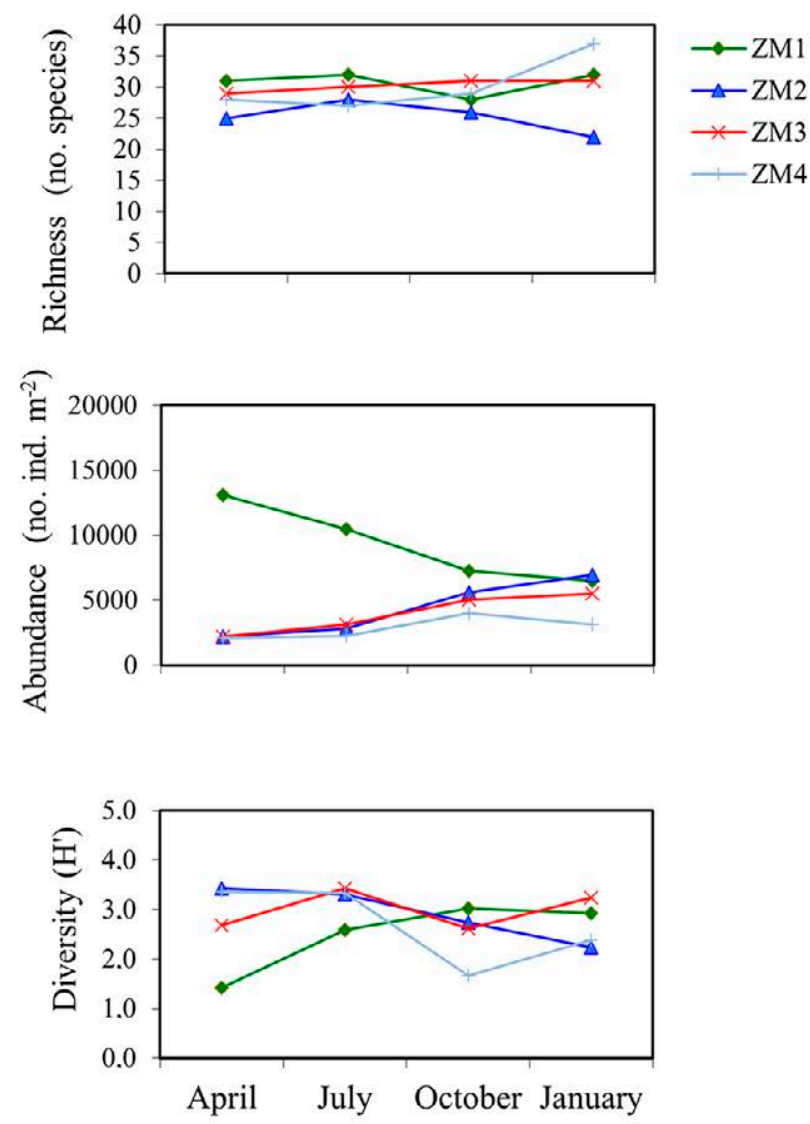

bed. The mean annual macrofauna abundance was 5201 ind. $\mathrm{m}^{-2}$ (Table 3). The class Gastropoda was the most abundant taxonomic group, accounting for $85 \%$ of the total annual mean abundance. This abundance was highly related to the presence of $H$. ulvae (3250 ind. $\mathrm{m}^{-2} ; 62 \%$ ) and $B$. reticulatum $\left(876\right.$ ind. $\mathrm{m}^{-2}$; $17 \%)$. The most frequently occurring species were $H$. reticulata (10\%), H. ulvae (92\%), Abra alba (92\%) and Venerupis sp. (92\%).

The contribution of $H$. ulvae, B. reticulatum, $L$. lacteus and $R$. parva in both seagrass beds comprised $>50 \%$ of the total number of individuals (Fig. 4). At sites with high freshwater influence, the gastropod $H$. ulvae represented $>45 \%$ (Z. marina, ZM1) and $>70 \%$ (Z. noltei, $\mathrm{ZN} 1$ ) of the total abundance.

No seasonal patterns were detected in the richness, abundance and diversity of the benthic fauna (Fig. 5). For these two species, the highest macrofauna abundances were recorded at sites with the main riverine influence (ZM1 and ZN1). In the bed of Z. noltei the spatial gradient was noticeable, with abundance increasing towards the sites with higher freshwater influence (ZN1), while richness and diversity increased through the sites with the main marine influence (ZN3).

Benthic macrofauna structure was markedly different in each seagrass bed (Fig. 6A). The benthic structure in $Z$. marina responded to seasonal and

\section{B, Zostera noltei}
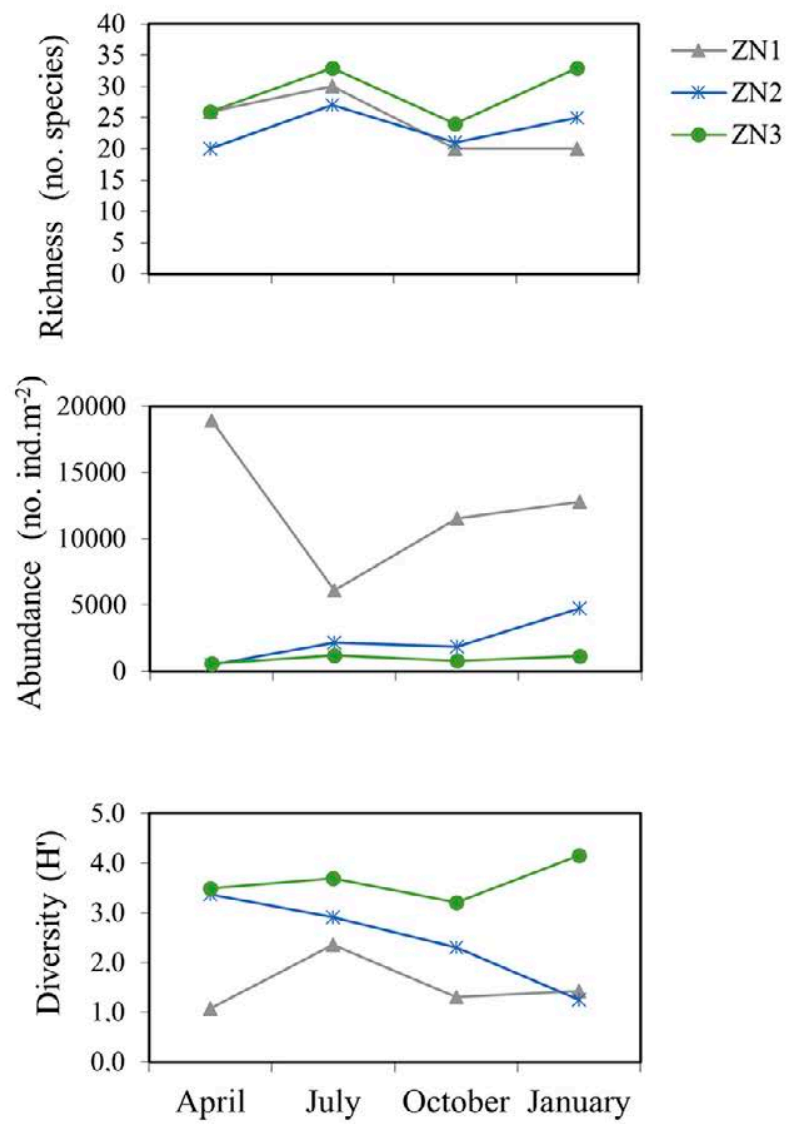

Fig. 5. - Seasonal variation (2000-2001) in the richness (no. species), abundance (ind. $\mathrm{m}^{-2}$ ) and benthic macrofauna diversity $\left(\mathrm{H}^{\prime}\right)$ in Zostera marina (ZM1-ZM4) (A) and Zostera noltei (ZN1-ZN3) beds (B). 
A Zostera marina and Zostera noltei

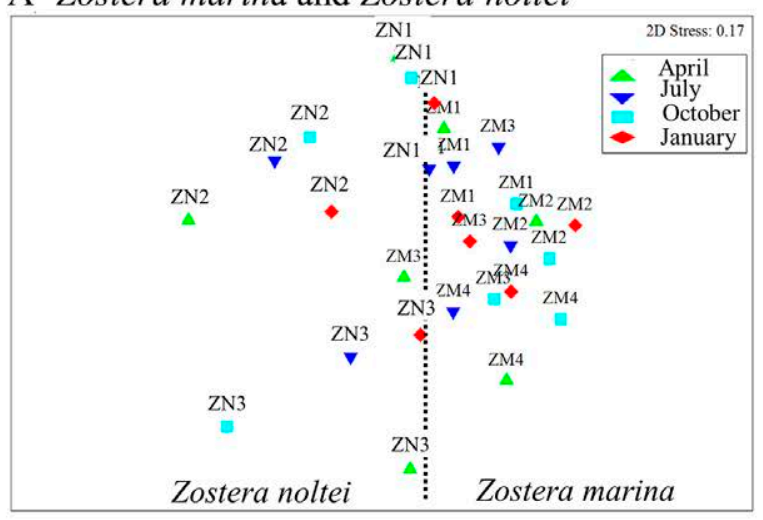

B Zostera marina

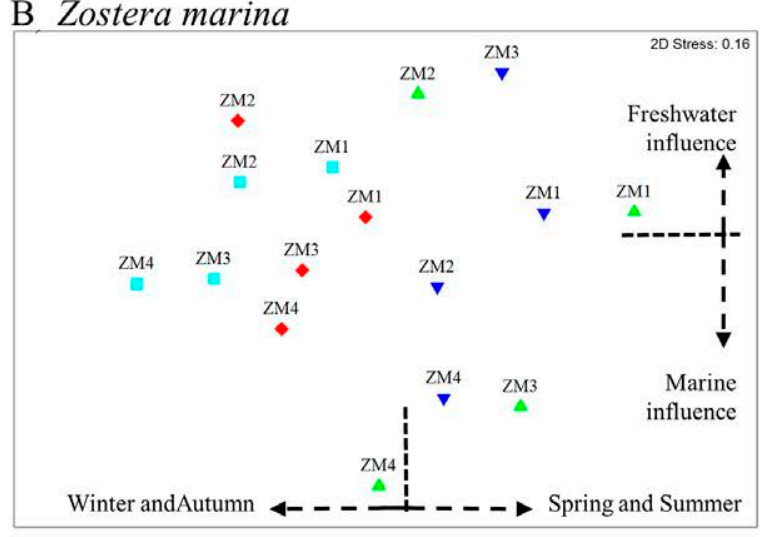

C Zostera noltei

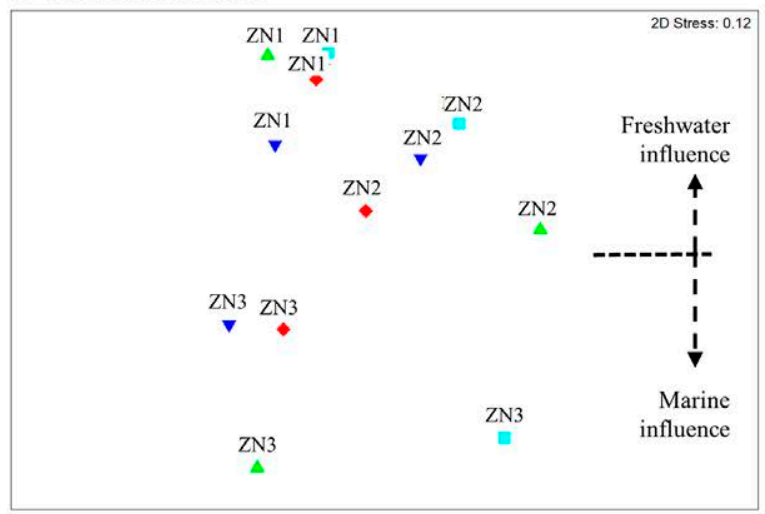

Fig. 6. - Multidimensional scaling analysis ordination of the sampling sites showing month groups: Zostera marina and Zostera noltei beds (A); Zostera marina bed (ZM1-ZM4) (B); and Zostera noltei bed (ZN1-ZN3) (C). Dashed lines indicate the spatial (marine and freshwater influence) and the seasonal gradients (winter and autumn, spring and summer) in the beds.

spatial patterns (Fig. 6B). The ordination analysis showed differences in the invertebrates' structure between spring and summer (April-July) and autumn and winter (October-January). Moreover, sites were arranged along the axial channel of the river, showing differences between those with freshwater (ZM1, $\mathrm{ZM} 2$ ) and marine influence (ZM4 and ZM3). In the Z. noltei bed (Fig. 6C) differences in the structure correlating to the salinity gradient were also observed (from $\mathrm{ZN1}$ to $\mathrm{ZN} 3$ ), although no seasonal patterns were found.

\section{DISCUSSION}

The present work analyses a meadow that maintained large populations of Zostera marina and Zostera noltei during the decline observed in the Bay of Santander from 1984 to the early 2000s. The significance of this kind of resilient meadow resides in its implications for management. These areas may function as seed sources and allow the recovery of lost areas (Calleja et al. 2017). When considering seagrass resistance and recovery, it is generally agreed that the greater the trait variability, the more likely the system is to survive periods of stress (Maxwell et al. 2014). A main aspect of such studies is to understand how local factors are compromising and, in some cases, contributing to the resilience of seagrass ecosystems (Unsworth et al. 2015). Although this study does not focus on analysing the causes, there is evidence in the literature suggesting that exposure to certain environmental stresses may enable individuals or communities to adapt to drivers and improve their resistance (Maxwell et al. 2014, Calleja et al. 2017).

In contrast with the findings of the literature on other Atlantic estuaries (e.g. Cochón et al. 2005, Martin et al. 2010, Garmendia et al. 2017), in the Bay of Santander the decline was followed by a fast recovery characterized by patches of vegetation alternating in space and time. Today, Z. marina and Z. noltei occupy most of the shallow tidal flats in the Bay of Santander (Ondiviela et al. 2015), and the high recovery rate observed suggests that resilient meadows played an important role in this process. At the local scale, recolonization processes can be driven by resilient meadows able to absorb disturbances and adapt to change during acute decline periods (Holling 1973).

To better understand resilient meadows, La Barquería was characterized by analysing plant traits (biomass, density, leaf width and length) and benthic assemblages along two factors of variation: seasonality and freshwater influence. In La Barquería Z. marina and Z. noltei are perennial. Both species display a similar and noticeable seasonal growth pattern related to the summer peaks in the photosynthetically active radiation and the sea surface temperature (Lee et al. 2007, Ondiviela et al. 2014; Fig. 7). They also show a unimodal biomass pattern, which is a common feature of seagrass meadows found in temperate shallow waters (Olesen and Sand-Jensen 1994, Laugier et al. 1999, Lee et al. 2007). During the spring, new leaves are produced and grow in both length and width. During the summer, when there is plenty of activity, these two seagrass species reach their annual maximum biomass. Beginning in the fall (e.g. September), the plants achieve their maximum length and lose mature leaves, which are the longest and have the highest biomass. Likewise, a generic relationship is found between the biomass and shoot density of the beds and the spatial gradient along the river discharge, which increases upstream of the river, through the sites with high freshwater influence.

For Z. marina, the observed mean aboveground biomass and shoot density resemble those of other 

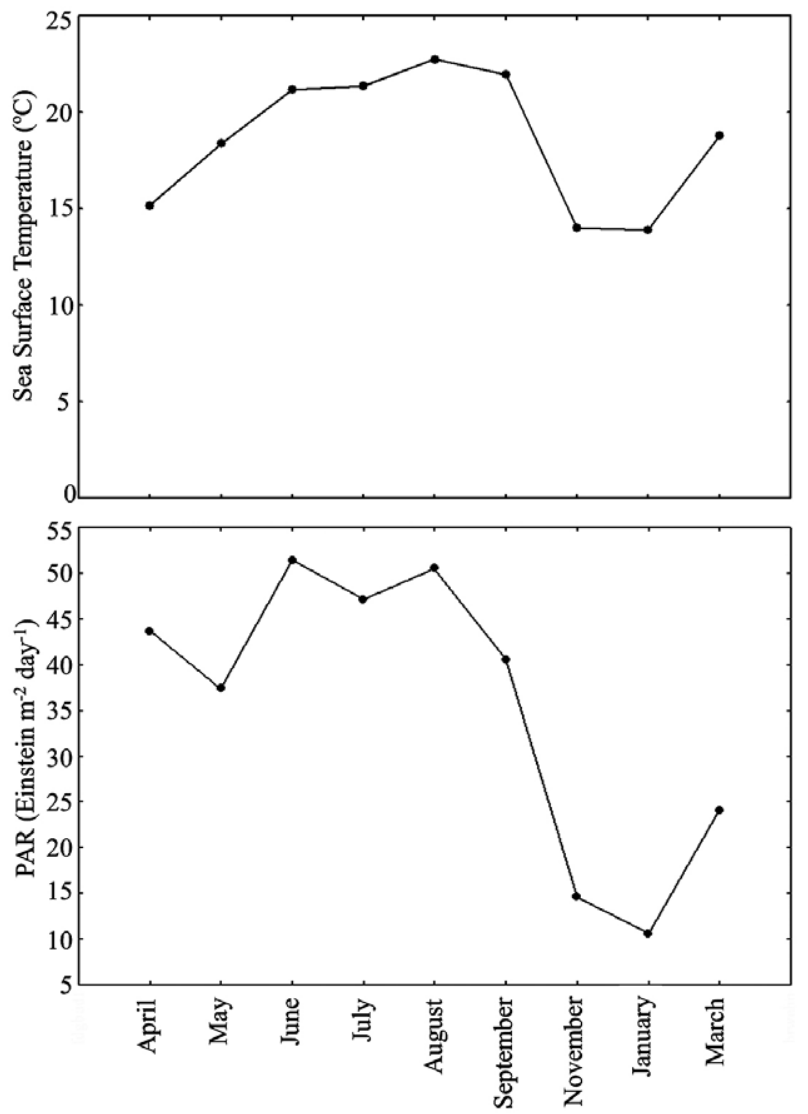

Fig. 7. - Water temperature $\left({ }^{\circ} \mathrm{C}\right)$ and photosynthetically active radiation (PAR, einstein $\mathrm{m}^{-2} \mathrm{day}^{-1}$ ) in the Bay of Santander (2000-2001).

temperate and well conserved meadows in estuaries of southern Spain (220-402 shoots m ${ }^{-2}$; 8.4-90 g DW m Rueda et al. 2008) and the Atlantic coast of Canada (460-1046 shoots $\mathrm{m}^{-2}$; 20-120 g DW m${ }^{-2}$; Wong et al. 2013). The observed values for $Z$. nolte $i$ also agree well with data from comparable climatic conditions in the southwestern Iberian Peninsula (2000-10000 shoots $\mathrm{m}^{-2}$; 6-13 cm leaf length; 0.09-0.17 $\mathrm{cm}$ leaf wide; Peralta 2000, Peralta et al. 2000); and the Arcachon Bay in France (40-110 $\mathrm{g} \mathrm{DW} \mathrm{m}^{-2}$; 4000-22000 shoots $\mathrm{m}^{-2}$; Auby and Labourgm 1996).

Invertebrate assemblages frequently reflect habitat variability. Physical factors typically determine macro-scale (e.g. kilometre scale) patterns of assemblages, while food distribution, habitat structure, biotic interactions and reproductive behaviour cause micro-scale (e.g. metre scale) heterogeneity (Baeta et al. 2009, Cunha et al. 2013, Materatski et al. 2016). In La Barquería relationships between environmental gradients, aboveground biomass and benthic assemblages appear to be helping define the composition of the meadow. These factors might be related to the abundance and distribution of Hydrobia ulvae in zones with a high freshwater influence and the associations between Rissoa parva and Z. marina and between Bittium reticulatum and $Z$. noltei in areas with a high marine influence. Seagrasses are frequently characterized by the abundance of certain faunal groups (Cardoso et al. 2008, Virnsten et al. 1984). In La Barquería grazers dominate sites characterized by low hydrodynamics, stable sediment and relatively high tidal levels. The consequence is a spatial gradient along the axial channel of the river, which is highly evident in the Z. noltei bed, with fauna abundance declining and diversity and richness increasing towards the areas where the marine influence is higher. By contrast, seasonal changes caused by temperature and irradiance do not highly affect fauna assemblages.

\section{CONCLUSIONS}

The present study characterizes the resilient meadow of La Barquería at the precise moment when the population of Zostera marina and Zostera noltei was decreasing in the Bay of Santander (from 1984 to the early 2000s). A number of resilient parameters related to plant traits (biomass, density, leaf length and width) and benthic assemblages along two factors of variation (seasonality and freshwater influence) were analysed. In La Barquería, Z. marina and Z. noltei beds display traits of resistance for remaining resilient. The two species show high variability in these traits, making evident that the greater the trait variability, the more likely the system is to survive periods of stress. The biomass, density, morphological traits and benthic assemblages vary as a function of seasonal and spatial gradients. This variation is probably related to the summer peaks in the photosynthetically active radiation, the sea surface temperature and the freshwater influence along the discharge of the Miera River. A small number of species dominate the structure and composition of the benthic macrofauna. The gradients along the river discharge determine the abundance and distribution of Hydrobia ulvae in zones with a high freshwater influence and the associations between Rissoa parva and Z. marina and between Bittium reticulatum and Z. nolte $i$ in zones with a high marine influence. This work provides the first seagrass data in Cantabria and may constitute a baseline study for the Bay of Biscay.

\section{ACKNOWLEDGEMENTS}

The Marcelino Botín Foundation through the Eduardo Miguel Fernandez Section III supported this work. The authors would like to thank Izascum Preciado, Gabriel Calderón, Inés Santiuste and Beatriz Echávarri for the collaboration provided. They would also like to thank the reviewers for their extraordinarily useful comments.

\section{REFERENCES}

Auby I., Labourgm P.J. 1996. Seasonal dynamics of Zostera noltii Hornem., in the Bay of Arcachon (France). J. Sea. Res. 35: 269-277.

https://doi.org/10.1016/S1385-1101(96)90754-6

Baeta A., Valiela I., Rossi F., et al. 2009. Eutrophication and trophic structure in response to the presence of the eelgrass Zostera noltii. Mar. Biol. 156: 2107-2120. https://doi.org/10.1007/s00227-009-1241-y

Bergmann N., Winters G., Rauch G., et al. 2010. Population-specificity of heat stress gene induction in northern and southern eelgrass Zostera marina populations under simulated global warming. Mol. Ecol. 19: 2870-2883. 
https://doi.org/10.1111/j.1365-294X.2010.04731.x

Calleja F., Galván C., Silió-Calzada A., et al. 2017. Long-term analysis of Zostera noltei: A retrospective approach for understanding seagrasses' dynamics. Mar. Environ. Res. 130: 3-105. https://doi.org/10.1016/j.marenvres.2017.07.017

Cardoso P.G., Raffaelli D., Pardal M.A. 2008. The impact of extreme weather events on the seagrass Zostera noltii and related Hydrobia ulvae population. Mar. Pollut. Bull. 56: 483-492. https://doi.org/10.1016/j.marpolbul.2007.11.006

Cochón G., Sánchez J.M. 2005. Variations of seagrass beds in Pontevedra (northwestern Spain): 1947-2001. Thalassas 21: 9-19.

Cunha A.H., Assis J., Serrão E. 2013. Seagrass in Portugal: A most endangered marine habitat. Aquat. Bot. 104: 193-203. https://doi.org/10.1016/j.aquabot.2011.08.007

Davis T., Harasti D., Smith S. et al. 2016. Using modelling to predict impacts of sea level rise and increased turbidity on seagrass distributions in estuarine embayments. Est. Coast. Shelf Sci. 181: 294-301. https://doi.org/10.1016/j.ecss.2016.09.005

Dolch T., Buschbaum C., Reise K. 2013. Persisting intertidal seagrass beds in the northern Wadden Sea since the 1930s. J. Sea. Res. 82: 134-141. https://doi.org/10.1016/j.seares.2012.04.007

Ehlers A., Worm B., Reusch T. B. 2008. Importance of genetic diversity in eelgrass Zostera marina for its resilience to global warming. Mar. Ecol. Prog. Ser. 355: 1-7. https://doi.org/10.3354/meps07369

Folk R.L. 1954. The distinction between grain size and mineral composition in sedimentary rock nomenclature. J. Geology 62: 344-359. https://doi.org/10.1086/626171

Folmer E., Beusekom van J., Dolch T., et al. 2016. Consensus forecasting of intertidal seagrass habitat in the Wadden Sea. J. Appl. Ecol. 53: 1800-1813. https://doi.org/10.1111/1365-2664.12681

Galván C., Juanes J.A., Puente A. 2010. Ecological classification of European transitional waters in the North-East Atlantic ecoregion. Est. Coast. Shelf Sci. 87: 442-450. https://doi.org/10.1016/j.ecss.2010.01.026

Garmendia J.M., Valle M., Borja A., et al. 2017. Effect of trampling and digging from shellfishing on Zostera noltei (Zosteraceae) intertidal seagrass beds. Sci. Mar. 81: 121-128 https://doi.org/10.3989/scimar.04482.17A

Holling C.S. 1973. Resilience and stability of ecological systems. Annu. Rev. Ecol. Syst. 4: 1-23. https://doi.org/10.1146/annurev es.04.110173.000245

Hughes B.B., Hammerstrom K.K., Grant N.E., et al. 2016. Trophic cascades on the edge: Fostering seagrass resilience via a novel pathway. Oecologia 182: 231-241. https://doi.oro/10.1007/s00442-016-3652-z

Kruskal J.B., Wish M. 1978. Multidimensional Scaling. Sage University Paper Series on Quantitative Applications in the Social Sciences, 11. Sage Publications, London. 93 pp. https://doi.org/10.4135/9781412985130

Laugier L., Rigollet V., de Casabianca M.L. 1999. Seasonal dynamics in mixed eelgrass beds, Zostera marina L. and Zostera noltii Hornem., in a Mediterranean coastal lagoon (Thau lagoon, France). Aquat. Bot. 63: 51-69. https://doi.org/10.1016/S0304-3770(98)00105-3

Lee K.S., Park S.R., Kim Y.K. 2007. Effects of irradiance, temperature, and nutrients on growth dynamics of seagrasses: A review. J. Exp. Mar. Biol. Ecol. 350: 144-175. https://doi.org/10.1016/j.jembe.2007.06.016

Lotze H.K., Lenihan H.S., Bourque B.J., et al. 2006. Depletion, degradation, and recovery potential of estuaries and coastal seas. Science 312: 1806-1809. https://doi.org/10.1126/science.1128035

Macreadie P.I., York P.H., Sherman C.D. 2014. Resilience of Zostera muelleri seagrass to small-scale disturbances: the relative importance of asexual versus sexual recovery. Ecol. Evol. 4: 450-461. https://doi.org/10.1002/ece3.933

Martin P., Sebastien D., Gilles T., et al. 2010. Long-term evolution (1988-2008) of Zostera spp. Meadows in Arcachon Bay (Bay of
Biscay). Est. Coast. Shelf Sci. 87: 357-366.

https://doi.org/10.1016/j.ecss.2010.01.016

Materatski P., Vafeiadou A.M., Moens T., et al. 2016. Structural and functional composition of benthic nematode assemblages during a natural recovery process of Zostera noltii seagrass beds. Estuar. Coast. 39: 1478-1490. https://doi.org/10.1007/s12237-016-0086-0

Maxwell P.S., Pitt K.A., Burfeind D.D., et al. 2014. Phenotypic plasticity promotes persistence following severe events: physiological and morphological responses of seagrass to flooding. J. Ecol. 102: 54-64 https://doi.org/10.1111/1365-2745.12167

Olesen B., Sand-Jensen K. 1994. Demography of shallow eelgrass (Zostera marina) populations-shoot dynamics and biomass. J. Ecol. 82: 379-390. https://doi.org/10.2307/2261305

Ondiviela B., Gomez A.G., Puente A., et al. 2013. A pragmatic approach to define the ecological potential of water bodies heavily modified by the presence of ports. Environ. Sci. Policy 33: 320-331 https://doi.org/10.1016/j.envsci.2013.07.001

Ondiviela B., Losada I.J., Lara J.L., et al. 2014. The role of seagrasses in coastal protection in a changing climate. Coast. Eng. 87: $158-168$ https://doi.org/10.1016/j.coastaleng.2013.11.005

Ondiviela B., García-Castrillo G., Recio M., et al. 2015. Praderas de angiospermas marinas de Cantabria. In: Ruiz J.M., Guillén J.E., Ramos Segura A., et al. (eds), Atlas de las Praderas Marinas de España. IEO/IEL/UICN, Murcia-Alicante-Málaga, pp. 566-593.

Orth R.J., Carruthers T.J.B., Dennison W.C., et al. 2006. A global crisis for seagrass ecosystems. Bioscience 56: 987-996. https://doi.org/10.1641/0006-3568(2006)56[987:AGCFSE]2.0 $\mathrm{CO} ; 2$

Peralta G. 2000. Estudios sobre el crecimiento en Zostera noltii Hornem.: Dinámica estacional y aspectos ecofisiológicos. PhD thesis. Universidad de Cádiz, 229 pp.

Peralta G., Pérez-Lloréns J.L., Hernández I., et al. 2000. Morphological and physiological differences of two morphotypes of Zostera noltii Hornem., from the southwestern Iberian Peninsula. Helgoland. Mar. Res. 54: 80- 86. https://doi.org/10.1007/s101520050005

Rueda J.L., Salas C., Marina P. 2008. Seasonal variation in a deep subtidal Zostera marina L., bed in southern Spain (western Mediterranean Sea). Bot. Mar. 51: 92-102. https://doi.org/10.1515/BOT.2008.016

Short F.T., Polidoro B., Livingstone S.R., et al. 2011. Extinction risk assessment of the world's seagrass species. Biol. Conserv. 144: 1961-1971. https://doi.org/10.1016/j.biocon.2011.04.010

Unsworth R.K.F., Collier C.J., Waycott M., et al. 2015. A framework for the resilience of seagrass ecosystems. Mar. Pollut. Bull. 100: 34-46. https://doi.org/10.1016/j.marpolbul.2015.08.016

Virnsten R.W., Nelson W.G., Lewis F.G., et al. 1984. Latitudinal patterns in seagrass epifauna: Do patterns exist, and can they be explained? Estuaries 7: 310-330. https://doi.org/10.2307/1351616

Waycott M., Duarte C.M., Carruthers T.J.B., et al. 2009. Accelerating loss of seagrasses across globe threatens coastal ecosystems. Proc. Natl. Acad. Sci. 106: 12377-12381. https://doi.org/10.1073/pnas.0905620106

Wentworth C.K. 1922. A scale of grade and class terms for clastic sediments. J. Geol. 30: 377-392. https://doi.org/10.1086/622910

Wong M.C., Bravo M.A., Dowd M. 2013. Ecological dynamics of Zostera marina (eelgrass) in three adjacent bays in Atlantic Canada. Bot. Mar. 56: 413-424. https://doi.org/10.1515/bot-2013-0068

Yaakub S.M., McKenzie L.J., Erftemeijer P.L., et al. 2014. Courage under fire: Seagrass persistence adjacent to a highly urbanised city-state. Mar. Pollut. Bull. 83: 417-424 https://doi.org/10.1016/j.marpolbul.2014.01.012 